\title{
Prevalence of Gastrointestinal Parasites in Horses of Central Mexico
}

\author{
Camilo Romero ${ }^{1}$, Rafael Heredia ${ }^{2,3 *}$, Laura Miranda ${ }^{1}$, Mauricio Arredondo ${ }^{4}$ \\ ${ }^{1}$ DERMAVET, Veterinary Hospital, Iztapalapa, Mexico City, Mexico \\ ${ }^{2}$ CIVET, Veterinary Integral Center, Animal Health and Welfare, Ecatepec, Estado de Mexico, Mexico \\ ${ }^{3}$ Universitary Center UAEM Amemeca, Autonomous University of Mexico State, Estado de Mexico, Mexico \\ ${ }^{4}$ Guanajuato University, Irapuato-Salamanca Campus, Life Sciences Division, Irapuato, Guanajuato, Mexico \\ Email: ^rafaesbirro@hotmail.com
}

How to cite this paper: Romero, C., Heredia, R., Miranda, L. and Arredondo, M. (2020) Prevalence of Gastrointestinal Parasites in Horses of Central Mexico. Open Journal of Veterinary Medicine, 10, 117-125 https://doi.org/10.4236/ojvm.2020.108010

Received: March 23, 2020

Accepted: August 10, 2020

Published: August 13, 2020

Copyright (C) 2020 by author(s) and Scientific Research Publishing Inc. This work is licensed under the Creative Commons Attribution International License (CC BY 4.0).

http://creativecommons.org/licenses/by/4.0/

\begin{abstract}
Equines are affected by a large number of endoparasites, these can cause gastrointestinal signs, respiratory, poor performance, slow growth and even cause sudden death. The presence of parasites can be associated with various factors related to the animal and environmental or geographical factors. The prevalence of gastrointestinal parasite infection and risk factors in horses were evaluated. Stool samples belonging to 218 horses from different regions of central Mexico were analyzed by coproparasitological concentration-flotation technique. The fecal examinations were carried out from February to August in 2017. Among the 218 samples that were examined, 103 (47.24\%) were found to be positive with several gastrointestinal parasites, with Strongylus spp. being the most prevalent (23.85\%) followed by Trichostrongylus spp. (21.56\%) and Parascaris spp. (11.93\%). Breed and place of origin were significantly associated with helminth infection. Sex was associated as a significant risk factor $(\mathrm{p}<0.01)$ with the infection by Strongylus spp. on females and by Anoplocephala, on males. In central Mexico, gastrointestinal helminth infection appears to be relatively low.
\end{abstract}

\section{Keywords}

Gastrointestinal Helminths, Prevalence, Horses, Parasites, Risk Factors

\section{Introduction}

Despite millions of years of evolution, horses are highly susceptible to endoparasites and ectoparasites at any stage of their life. More than 60 species of gastrointestinal parasites are common in equines, whilst external parasites such as 
ticks, lice and mites, can act as vectors for many parasitic and bacterial diseases [1]. Infection can occur due to climatic, geographic and biological factors. Nowadays, emphasis is placed on climate change, as some parasites have modified their biological cycle as a result of temperature, precipitation and humidity changes [2]. Prevalence of gastrointestinal parasites in horses is associated with modification of their biological cycle, and to resistance to deworming drugs. The degree of damage caused to the horse by parasites will directly depend on the species and quantities of helminths, in addition to the immune response of the host [3].

The helminths that affect horses are primarily those belonging to the phylum Nematoda, including species like: Strongylus spp., Parascaris equorum, Oxyuris equi, Trichostrongylus spp., and Dyctiocaulus spp. [4]. Considered to be the most prevalent parasites worldwide, all grazing horses could potentially acquire any of these species [5]. In general, gastrointestinal nematode diagnosis is carried out through coproparasitoscopic examinations, which consist of observing the presence and morphological characteristics of larvae and eggs, which comprised determination and quantification of the parasitic load.

Depending on the species and parasitic load, it is possible to determine if it is advisable or not to carry out deworming [6]. Clinical signs can be, weight loss, dysphagia, colic manifestations caused by gastric and intestinal ulceration and in some cases, perforating ulcers, gastric obstruction volvulus, diarrhea, as well as induced anemia, amongst other complications [7].

Parasitosis control is a challenge for veterinarians, since the anthelminths used to treat them mainly include the benzimidazoles (mebendazole, febendazole, oxybendazole), to which studies have reported that parasites have developed drug resistance to over the years, resulting ineffective treatments [8]. However, macrocyclic lactones such as ivermectin have shown greater efficacy in reducing the presence of parasites [9]. when formatting individual papers, 2) automatic compliance to electronic requirements that facilitate the concurrent or later production of electronic products, and 3) conformity of style throughout a journal paper. Margins, column widths, line spacing, and type styles are built-in; examples of the type styles are provided throughout this document and are identified in italic type, within parentheses, following the example. Some components, such as multi-leveled equations, graphics, and tables are not prescribed, although the various table text styles are provided. The formatter will need to create these components, incorporating the applicable criteria that follow.

\section{Materials and Methods}

\subsection{Study Area}

The present study was carried out from February to August, 2017, in the Parasitology Laboratory of Companion Animal Veterinary Clinic of University Center UAEM Amecameca. The study was reviewed and endorsed by the ethics committee of the University Center UAEM Amecameca. 


\subsection{Selection of Animals}

We included 218 horses, who came to the clinic for consultation, from the different regions of central Mexico: Amecameca, Mexico City, Chalco, Cuautla, Ecatzingo, Huehetoca, Ixtapaluca, Juchitepec, Morelos, Ozumba, Ocuituco, Texcoco, Tlalmanalco, Valle de Chalco, Xalatlalco and Yecapixtla. Direct rectum feces samples were taken from every horse. The samples were analyzed by the concentration-flotation technique. The inclusion criteria were equines of any breed, sex and indistinct age, with the previous consent of the owner, by means of an informed consent letter. Horses that were dewormed two months before the study were excluded. Each animal was identified by a clinical sheet with epidemiological data.

\subsection{Sample Analysis}

The feces samples were analyzed with the coproparsitoscopic concentration-flotation technique, using a zinc sulfate solution with a specific density of $1.18 \mathrm{~g} / \mathrm{ml}$ [10], processed samples were then observed under microscope using $4 \times$, $10 \times, 40 \times$ and $100 \times$ objective lenses in order to identify parasitic forms. The results of the analysis were reported as the presence or absence of eggs and/or larvae.

\subsection{Data Analysis}

The data were analyzed using the Shapiro Wilk test in order to determine the distribution type. As no normal distribution was evident, the data were therefore analyzed using Chi-square tests so as to determine association between the presence of parasites and the following variables: place of origin, age (by parasite) and sex (by parasite). Additionally, Fisher's exact test was applied to compare parasite presence in the following groups: breed (pure breed and crossbreed), sex (male and female) and age (adult and colt).

\section{Results}

Of the 218 equines included in this study, 103 were positive for some type of parasite, so the overall prevalence was $47.24 \%$. Of the 103 positive horses, 55 (53.39\%) were female and $48(46.61 \%)$ were male, 60 (58.25\%) were adults and 43 (41.25\%) were colts.

Table 1 shows the comparison between prevalence of gastrointestinal parasites (GIP) in equines of pure breed and cross breed. A significant difference was found, showing a higher prevalence of GIP in equines of pure breed $(\mathrm{p}=0.02)$ Furthermore, the group of pure breed horses presented an association $\left(\mathrm{X}^{2}=\right.$ $5.43, \mathrm{p}=0.01$ ) with the presence of GIP (Table 2).

The comparison between males and females did not show differences, sharing similar values, and there was no association with the presence of GIP by sex (Table 3 and Table 4). The same result was found when comparing parasite presence by age (colts and adults), showing no difference, in addition to no association of GIP with age (Table 5 and Table 6). 
Table 7 shows the results of the association of place of origin with the prevalence of GIP; horses from Morelos display the highest prevalence $\left(\mathrm{X}^{2}=43.01, \mathrm{p}\right.$ $=0.0003$ ), and had the greatest association with GIP.

We compared the prevalence of GIP between colts and adults by parasite species, and no differences were found (Table 8), although it should be noted that the most prevalent parasites were Strongylus spp., followed by Trichostrongylus spp. and then Parascaris spp., as seen in Table 8.

Comparing males and females horses per parasite species, it was observed that females had a higher prevalence of Strongylus spp. $(\mathrm{p}=0.01)$, whereas males showed a higher prevalence $(\mathrm{p}=0.01)$ of Anoplocephala spp. (Table 9). There

Table 1. Comparison of the prevalence of GIP among crossbreed and breed horses.

\begin{tabular}{ccccc}
\hline & Positive (\%) & Negative (\%) & Total & p-value \\
\hline Crossbreed & $35(16.06)$ & $23(10.55)$ & 58 & \\
Breed & $68(31.19)$ & $92(42.20)$ & 160 & $0.02^{*}$ \\
Total & 103 & 115 & 218 & \\
\hline
\end{tabular}

2-Tail-Fisher's exact test $\mathrm{p}<0.05$.

Table 2. Association of prevalence of GIP in crossbreed and breed horses.

\begin{tabular}{ccccc}
\hline & Positive $\mathrm{n}=\mathbf{1 0 3}$ & Negative $\mathrm{n}=\mathbf{1 1 5}$ & $\mathrm{X}^{\mathbf{2}}$ & $\mathrm{p}$-value \\
\hline Crossbreed & 16.06 & 10.55 & 5.43 & $0.01^{\star}$ \\
Breed & 31.19 & 42.20 & & \\
\hline
\end{tabular}

Chi-square test ${ }^{*} \mathrm{p}<0.05$.

Table 3. Comparison of the prevalence of GIP between males and females.

\begin{tabular}{ccccc}
\hline & Positive (\%) & Negative (\%) & Total & p-value \\
\hline Female & $55(25.23)$ & $51(23.39)$ & 106 & \\
Male & $48(22.02)$ & $64(29.36)$ & 112 & 0.22 \\
Total & 103 & 115 & 218 & \\
\hline
\end{tabular}

2-Tail-Fisher's exact test $\mathrm{p}<0.05$.

Table 4. Association of prevalence of GIP and sex.

\begin{tabular}{ccccc}
\hline & Positive $\mathbf{n}=103$ & Negative $\mathbf{n}=115$ & $\mathrm{X}^{2}$ & p-value \\
\hline Female & 25.23 & 23.39 & 1.78 & 0.18 \\
Male & 22.02 & 29.36 & & \\
\hline
\end{tabular}

Chi-square test ${ }^{*} \mathrm{p}<0.05$.

Table 5. Comparison of the prevalence of GIP by age.

\begin{tabular}{rcccc}
\hline & Positive (\%) & Negative (\%) & Total & p-value \\
\hline Adult & $60(27.52)$ & $77(35.32)$ & 137 & \\
Colt & $43(19.72)$ & $38(17.43)$ & 81 & 0.20 \\
Total & 103 & 115 & 218 & \\
\hline
\end{tabular}

2-Tail-Fisher's exact test $\mathrm{p}<0.05$. 
Table 6. Association of prevalence of GIP and age.

\begin{tabular}{ccccc}
\hline & Positive $\mathbf{n}=103$ & Negative $\mathbf{n}=115$ & $\mathrm{X}^{2}$ & p-value \\
\hline Adult & 27.52 & 35.32 & 1.76 & \\
Colt & 19.72 & 17.43 & & 0.18 \\
\hline
\end{tabular}

Chi-square test ${ }^{*} \mathrm{p}<0.05$.

Table 7. Association of prevalence of GIP and zone.

\begin{tabular}{|c|c|c|c|c|}
\hline & Positive $n=103$ & Negative $n=115$ & $\mathrm{X}^{2}$ & $\mathrm{p}$-value \\
\hline Amecameca & 2.29 & 4.13 & \multirow{16}{*}{43.01} & \multirow{16}{*}{$0.0003^{*}$} \\
\hline Mexico City & 7.34 & 17.43 & & \\
\hline Chalco & 5.96 & 7.80 & & \\
\hline Cuautla & 5.50 & 4.13 & & \\
\hline Ecatzingo & 1.38 & 0.46 & & \\
\hline Huehetoca & 1.83 & 0 & & \\
\hline Ixtapaluca & 2.29 & 5.50 & & \\
\hline Juchitepec & 1.83 & 0.46 & & \\
\hline Morelos & 3.21 & 0.46 & & \\
\hline Ozumba & 2.75 & 0 & & \\
\hline Ocuituco & 5.96 & 2.75 & & \\
\hline Texcoco & 0.46 & 2.75 & & \\
\hline Tlalmanalco & 1.38 & 1.83 & & \\
\hline Valle de Chalco & 0.46 & 1.83 & & \\
\hline Xalatlalco & 0.92 & 0 & & \\
\hline Yecapixtla & 1.83 & 0.46 & & \\
\hline
\end{tabular}

Chi-square test ${ }^{*} \mathrm{p}<0.05$, the value of $\mathrm{X}^{2}$ is in the state line with the highest association.

Table 8. Comparison of age prevalence per parasite.

\begin{tabular}{|c|c|c|c|c|c|}
\hline \multirow{2}{*}{ Parasite } & \multicolumn{2}{|c|}{ Positive (\%) } & \multicolumn{2}{|c|}{ Negative (\%) } & \multirow{2}{*}{ p-value } \\
\hline & Adult & Colt & Adult & Colt & \\
\hline Parascaris sp. & $19(8.72)$ & $7(3.21)$ & $118(54.13)$ & $74(33.94)$ & 0.28 \\
\hline Oxuris sp. & $5(2.29)$ & $2(0.92)$ & $132(60.55)$ & $79(36.24)$ & 1.0 \\
\hline Strongylus sp. & $28(12.84)$ & $24(11.01)$ & $109(50.00)$ & $57(26.15)$ & 0.14 \\
\hline Trichostrongylus sp. & $30(13.76)$ & $17(7.80)$ & $107(49.08)$ & $64(29.36)$ & 1.0 \\
\hline Eimeria spp. & $2(0.92)$ & $0(0)$ & 135 (61.93) & $81(37.16)$ & 0.53 \\
\hline Entamoeba spp. & $2(0.92)$ & $3(1.38)$ & 135 (61.93) & $78(35.78)$ & 0.36 \\
\hline Anoplocephala sp. & $7(3.21)$ & $3(1.38)$ & $130(59.63)$ & $78(35.78)$ & 0.74 \\
\hline Fasciola sp. & $2(0.92)$ & $1(0.46)$ & $135(61.93)$ & $80(36.70)$ & 1.0 \\
\hline
\end{tabular}

2-Tail-Fisher's exact test $\mathrm{p}<0.05$. 
Table 9. Comparison of prevalence by gender per parasite.

\begin{tabular}{cccccc}
\hline \multirow{2}{*}{ Parasite } & \multicolumn{2}{c}{ Positive (\%) } & \multicolumn{2}{c}{ Negative (\%) } & \multirow{2}{*}{ p-value } \\
\cline { 2 - 5 } & Female & Male & Female & Male & \\
\hline Parascaris sp. & $10(4.59)$ & $16(7.34)$ & $96(44.04)$ & $96(44.04)$ & 0.30 \\
Oxuris sp. & $5(2.29)$ & $2(0.92)$ & $101(46.33)$ & $110(50.46)$ & 0.26 \\
Strongylus sp. & $33(15.14)$ & $19(8.72)$ & $73(33.49)$ & $93(42.66)$ & $0.01^{*}$ \\
Trichostrongylus sp. & $25(11.47)$ & $22(10.09)$ & $81(37.16)$ & $90(41.28)$ & 0.51 \\
Eimeria spp. & $2(0.92)$ & $0(0)$ & $135(61.93)$ & $81(37.16)$ & 0.53 \\
Entamoeba spp. & $4(1.83)$ & $1(0.46)$ & $102(46.79)$ & $111(50.92)$ & 0.20 \\
Anoplocephala sp. & $1(0.46)$ & $9(4.13)$ & $105(48.17)$ & $103(47.25)$ & $0.01^{*}$ \\
Fasciola sp. & $3(1.38)$ & $0(0)$ & $103(47.25)$ & $112(51.38)$ & 0.11 \\
\hline
\end{tabular}

2-Tail-Fisher's exact test $\mathrm{p}<0.05$.

were no differences by sex for the other parasite species.

\section{Discussion}

The helminths found in this study are parasites that commonly affect horses, as reported in a study from Chiapas, Mexico, by Güiris and collaborators in a previous study [11] who identified the presence of 5 families from the phylum Nematoda and one family from the class Cestoda: Ascaridae, Kathlanidae, Oxyuridae, Strongylidae, Trichostrongylidae and Anoplocephalidae respectively, in naturally infected horses that had low medical supervision. We found more GIP species in addition to those described, such as Eimeria spp., Entamoeba spp. and Fasciola spp.

In the present study, the overall prevalence of the 8 species of gastrointestinal parasites was 47.24\% (103 of 218 horses from different regions of central Mexico). This was similar to the observations made by Levy et al. in Israel [12] and Matto et al. in India [13] who reported prevalences of $24 \%$ and $38.80 \%$ respectively. On the contrary, other studies by Mezgebu et al. in Ethiopia [14], Rehbein et al. [15] in Germany, Valdéz-Cruz et al. in Veracruz [16] Chemeda et al. in Ethiopia [17] Balzan et al. in Brazil [18] and Khan et al. in Pakistan [19] indicated higher prevalences of $80.95 \%, 77.5 \%, 91.3 \%, 94 \%, 63.96 \%$ and $78.3 \%$ respectively. Variation in prevalence rates may be due to the type of management, geographic area, seasonal variations or time scales used [20].

The highest GIP prevalence was displayed by the horses from Mexico city (Table 7), indicating a $7.34 \%$ of positive horses in comparison to the other places that were sampled in this study, which could be associated with the existence of higher population densities of equines here, which could provide a wide scope for propagation from one individual to another. Other reasons for higher GIP prevalence here could be due to climatic and environmental differences or an inadequate GIP control strategy [21]. Though in another study in 2012 from Poland [22] mention that the parasites of the genus Strongylus occur less frequently in horses, recent studies [18] [19] mention that these parasites have been 
noted as amongst those most commonly found in horses. Th.is coincides with our study, where the most dominant and most prevalent parasite was Strongylus spp. with a prevalence of $23.85 \%$ (Table 8), similar to the 34 and 24 prevalence reported by Ali and Yagoob [23] and by Levy et al. [12] respectively. There are also other studies from Pakistan [19], Ethiopia [14] and Germany [15] where this parasite had even higher prevalence rates; $75.6 \%, 66.7 \%, 60.8 \%$ respectively.

Access to grass, routinely deworming, breed, sex, season, geographic area [12] and emergence of drug-resistant strains are some of the risk factors that have been associated with parasite infection [22].

According to the occurrence of GIP based on sex, females were significantly $(\mathrm{p}<0.01)$ more affected than males by Strongylus sp. infections, too were significantly ( $\mathrm{p}<0.01$ ) more susceptible to infections by Anoplocephala sp. than females (Table 9). Khan et al. [19] also observed a significant difference between infection in females, which could be associated with pregnancy and lactation as causes of a decreased immunity. By contrast, no significant differences were found between genders in other studies [13] [14] [17].

It has been reported that horse breed is a factor significantly associated with helminth infection [12]. This coincides with our study, where horses of some breeds showed significantly greater infection $(\mathrm{p}<0.02)$ than in cross breeds (Table 1). Immunity develops following exposure to parasites; this is indicated to be the reason as to why young horses are more susceptible to helminth infections, as they have had less opportunities for exposure [19]. However, no significant differences were shown between young and adult animals in this study, as found by other studies [14] [24], in other studies, prevalence in foals on some farms was just as high as the level in some foals whose mothers were not treated with ivermectin near the time of foaling. This possibly indicated little or no decrease of prevalence in foals sucking ivermectin-treated mares. One study did show apparent reduced prevalence in foals whose dams were treated with the injectable formulation (no longer on the market) of ivermectin around the period of parturition [25], these studies also agree that also do not significantly associate age with parasite presence. This could be due to the lower number of young horses present in this study.

\section{Conclusion}

This study demonstrated the presence of at least eight types of gastrointestinal parasites in horses in different areas of central Mexico, observing a prevalence of $47.24 \%$ infected horses. In addition, like other studies, it is confirmed that breed, sex and geographic location are risk factors associated with susceptibility to infection. Adequate detection and implementation of new strategies for parasite control in equines is advisable.

\section{Conflicts of Interest}

The authors declare no conflicts of interest regarding the publication of this paper. 


\section{References}

[1] Dissanayake, S., Jayanthe Rajapakse, R.P.V. and Rajakaruna, R.S. (2017) Gastrointestinal Parasites of Domesticated and Feral Horses (Equus caballus) in Sri Lanka. Ceylon Journal of Science, 46, 17-26. https://doi.org/10.4038/cjs.v46i1.7414

[2] Díaz Sjostrom, P. and Cruz Quintana, S.M. (2017) Cambio climático: Efecto sobre la reemergencia de enfermedades infecciosas y parasitarias. Revista Electronica de Veterinaria, 18, 1-13.

[3] Forlano, M., Canelón, J., Mujica, F., Álvarez, E., Concepción, J. and Granda, F. (2012) Prevalencia de endoparásitos en caballo criollo venezolano en dos hatos del estado Apure-Venezuela. Gaceta de Ciencias Veterinarias, 17, 11-17.

[4] Herrera Benavides, Y.M., Perdomo Ayola, S.C. and Cardona Álvarez, J.A. (2015) Eficacia de la doramectina vía intramuscular sobre nematodos gastrointestinales en equinos. Revista de Medicina Veterinaria, 29, 41-49. https://doi.org/10.19052/mv.3445

[5] Anziani, O.S., Cooper, L.G., Cerutti, J., Fassola, L., Torrents, J., Masnyj, F. and Caffe, G. (2017) Pequeños estróngilos de los equinos. Eficacia clínica y periodo de reaparición de huevos luego del tratamiento con moxidectina y pirantel. FAVE Sección Ciencias Veterinarias, 16, 83-87. https://doi.org/10.14409/favecv.v16i2.6872

[6] Rivero-Perez, N., Zaragoza-Bastida, A., Vega-Sánchez, V., Olave-Leyva, I., VegaAngeles, J. and Peña-Jiménez, F. (2018) Identificación de los principales parásitos gastrointestinales en burros del Valle de Tulancingo. Abanico Veterinario, 8, 47-52. https://doi.org/10.21929/abavet2018.81.4

[7] Cardona, J., Álvarez Z, A. and Paredes, E. (2016) Ocurrencia de miasis cavitaria equina (Gasterophilus spp) y su relación con las úlceras gástricas secundarias en la mucosa escamosa en Temuco, Chile. CES Medicina Veterinaria y Zootecnia, 11, 78-87. https://doi.org/10.21615/cesmvz.11.1.8

[8] Anziani, O. and Ardusso, G. (2017) Resistencia a los antihelmínticos en nematodes intestinales que parasitan a los equinos en la Argentina. Revista de Investigaciones Agropecuarias, 43, 24-35.

[9] Saumell, C., Lifschitz, A., Baroni, R., Fusé, L., Bistoletti, M., Sagües, F., Bruno, S., Alvarez, G., Lanusse, C. and Alvarez, L. (2017) The Route of Administration Drastically Affects Ivermectin Activity against Small Strongyles in Horses. Veterinary Parasitology, 236, 62-67. https://doi.org/10.1016/j.vetpar.2017.01.025

[10] Coelho, W.M.D., Gomes, J.F., Falcao, A.X., Dos Santos, B.M., Soares, F.A., Suzuki, C.T.N., Do Amarante, A.F.T. and Bresciani, K.D.S. (2015) Comparative Study of Five Techniques for the Diagnosis of Canine Gastrointestinal Parasites. Revista Brasileira de Parasitologia Veterinária, 24, 223-226. https://doi.org/10.1590/S1984-29612015032

[11] Guïris, A.D.M., Rojas, H.N.M., Berovides, A.V., Sosa, P.J., Pérez, E.M.E., Cruz, A.E., Chávez, H.C., Moguel, A.J.A., Jimenez-Coello, M. and Ortega-Pacheco, A. (2010) Biodiversity and Distribution of Helminths and Protozoa in Naturally Infected Horses from the Biosphere Reserve "La Sierra Madre de Chiapas", México. Vet Parasitol, 170, 268-277. https://doi.org/10.1016/j.vetpar.2010.02.016

[12] Levy, S.T., Kaminiski-Perez, Y., Mandel, H.H., Sutton, G.A., Markovics, A. and Steinman, A. (2015) Prevalence and Risk Factor Analysis of Equine Infestation with Gastrointestinal Parasites in Israel. Israel Journal of Veterinary Medicine, 70, 32-40.

[13] Matto, T.N., Bharkad, G.P. and Bhat, S.A. (2015) Prevalence of Gastrointestinal Helminth Parasites of Equids from Organized farms of Mumbai and Pune. Journal of Parasitic Diseases, 39, 179-185. 
https://doi.org/10.1007/s12639-013-0315-4

[14] Mezgebu, T., Tafess, K. and Tamiru, F. (2013) Prevalence of Gastrointestinal Parasites of Horses and Donkeys in and around Gondar Town, Ethiopia. Open Journal of Veterinary Medicine, 3, 267-272. https://doi.org/10.4236/ojvm.2013.36043

[15] Rehbein, S., Visser, M. and Winter, R. (2013) Prevalence, Intensity and Seasonality of Gastrointestinal Parasites in Abattoir Horses in Germany. Parasitology Research, 112, 407-413. https://doi.org/10.1007/s00436-012-3150-0

[16] Valdéz-Cruz, M.P., Hernández-Gil, M., Galindo-Rodríguez, L. and Alonso-Díaz, M.A. (2013) Gastrointestinal Nematode Burden in Working Equids from Humid Tropical Areas of Central Veracruz, Mexico, and Its Relationship with Body Condition and Haematological Values. Tropical Animal Health and Production, 45, 603-607. https://doi.org/10.1007/s11250-012-0265-3

[17] Chemeda, R., Mekonnen, N., Muktar, Y. and Terfa, W. (2016) Study on Prevalence of Internal Parasites of Horses in and around Ambo Town, Central Ethiopia. American-Eurasian Journal of Agricultural \& Environmental Sciences, 16, 1051-1057.

[18] Balzan, A., Cazarotto, C.J., Grosskopf, R.K., Machado, G., Tonin, A.A. and Da Silva, A.S. (2017) Occurrence of Gastrointestinal Helminths in Horses and Risk Factors for Infection. Comparative Clinical Pathology, 26, 159-163. https://doi.org/10.1007/s00580-016-2360-8

[19] Khan, A., Rizwan, M., Samad, A., Sabeen, B.F., Bugti, F.S., Khan, M.A., Achakzai , S.K., Naeem, M., Sanya, H., Akhtar, W., Ashraf, S., Irum, N. and Shakoor, G. (2017) Epidemiological Prevalence and Role of Risk Factors in the Major Gastrointestinal Parasites in the Working Equines. Indo American Journal of Pharmaceutical Sciences, 4, 3923-3927.

[20] Adeppa, J., Ananda, K.J., Murthy, C.M.K. and Satheesha, G.M. (2016) Incidence of Gastro-Intestinal Parasites in Horses of Shimoga Region, Karnataka State. Journal of Parasitic Diseases, 40, 919-921. https://doi.org/10.1007/s12639-014-0605-5

[21] Schneider, S., Pfister, K., Becher, A.M. and Scheuerle, M. (2014) Strongyle Infections and Parasitic Control Strategies in German Horses-A Risk Assessment. BMC Veterinary Research, 10, Article No. 262. https://doi.org/10.1186/s12917-014-0262-Z

[22] Studzińska, M.B., Tomczuk, K., Demkowska-Kutrzepa, M. and Szczepaniak, K. (2012) The Strongylidae Belonging to Strongylus Genus in Horses from Southeastern Poland. Parasitology Research, 111, 1417-1421. https://doi.org/10.1007/s00436-012-3087-3

[23] Ali, A. and Yagoob, G. (2015) Survey on Fecal Gastrointestinal Parasitic Helminthes in Horses of Jockey Clubs in Ardabil City, Iran. Biological Forum, 7, 106-110.

[24] Belete, S. and Derso, S. (2015) Prevalence of Major Gastrointestinal Parasites of Horses in and around Mekelle (Quiha and Wukro). World Journal of Animal Science Research, 3, 1-10.

[25] Lyons, E.T. and Tolliver, S.C. (2014) Prevalence of Patent Strongyloides westeri Infections in Thoroughbred Foals in 2014. Parasitology Research, 113, 4163-4164.

https://doi.org/10.1007/s00436-014-4088-1 